\title{
10. STRATIGRAPHY, BY MEANS OF PLANKTONIC FORAMINIFERS, OF NEOGENE AND QUATERNARY SEDIMENTS NEAR THE CREST OF THE MID-ATLANTIC RIDGE, DSDP SITES 395 AND 396
}

\author{
V. A. Krasheninnikov, Geological Institute of the USSR Academy of Sciences, Moscow, USSR
}

\begin{abstract}
Holes 395 and 396 were drilled in the western and eastern flanks of the Mid-Atlantic Ridge, respectively. Hole 395 penetrated 93 meters of nannofossil-foraminifer ooze (above the basaltic basement). The basal layers are characterized by an impoverished microfauna of the uppermost Miocene (Globorotalia margaritae margaritae Zone) to lower Pliocene (Globorotalia margaritae evoluta Zone). All the zones of the Pliocene are evident higher up the section (Globorotalia margaritae evoluta, Globorotalia miocenica, Globorotalia tosaensis), as are some lower subzones of the Quaternary (Globorotalia crassaformis viola, Globorotalia crassaformis hessi, Globigerina calida calida). Above the basalts in Hole 396 there occur nannofossil and nannofossil-foraminifer oozes $(125 \mathrm{~m})$. The basal layers can be attributed to the Globorotalia fohsi fohsi Zone of the middle Miocene. Higher up there is a gap (the upper part of the middle Miocene and practically the entire upper Miocene are missing); and higher still, sediments of the same zones of the Pliocene and subzones of Quaternary are distributed, as in Hole 395. The assemblages of planktonic foraminifers have the features peculiar to tropical and subtropical microfaunas. Along with natural associations of planktonic foraminifers, one can recognize assemblages of perfectly sorted tests and redeposited species from underlying sediments. This testifies to active turbidity currents on the flanks of the ridge.
\end{abstract}

\section{INTRODUCTION}

During Leg 45, drilling was performed in two regions approximately symmetrical with respect to the crest of the Mid-Atlantic Ridge (Figure 1). Site 395 is on the western flank of the ridge $\left(22^{\circ} 45.35^{\prime} \mathrm{N}\right.$, $46^{\circ} 04.90^{\prime} \mathrm{W}$, water depth $4484 \mathrm{~m}$, magnetic anomaly $4)$; Site 396 is on the eastern flank $\left(22^{\circ} 58.88^{\prime} \mathrm{N}\right.$, $43^{\circ} 30.95^{\prime} \mathrm{W}$, water depth $4450 \mathrm{~m}$, magnetic anomaly $5)$. Holes penetrated a thin pile of organogenic sediments of the upper Cenozoic, above the basalts of oceanic basement.

\section{STRATIGRAPHIC SUBDIVISION OF NEOGENE AND QUATERNARY SEDIMENTS}

Upper Cenozoic organogenic sediments contain abundant planktonic foraminifers that enable their precise zonal subdivision.

\section{Site 395}

The character and age of the lowermost part of the sedimentary sequence $(9 \mathrm{~m})$ remain unknown, since sediments appear to have been shaken down the side of the hole on the contact of the drilling column with basalt (Core 10). This core contains intensely disturbed nannofossil-foraminifer oozes, together with cobbles and chips of serpentinite and gabbro; the oozes probably should be regarded as up-hole contamination. A normal (undisturbed) section begins with brown and yellowish brown calcareous clays $(4 \mathrm{~m}$ thick, Sections 9-4 through 9-6). Higher up, monotonous pale yellow and pale brown nannofossil-foraminifer oozes alternate with foraminifer sands $(80 \mathrm{~m})$.

Seven stratigraphic units may be distinguished on the basis of planktonic foraminifers:

1) The lowermost layers are characterized by relatively few and impoverished (as to the specific composition) planktonic foraminifers: Globigerinoides conglobatus, G. ruber, G. sacculifer, G. trilobus, Sphaeroidinellopsis seminulina, S. subdehiscens, S. sphaeroides, Globorotalia multicamerata, G. crassaformis, Globigerina nepenthes, Globoquadrina altispira; extremely scarce are Globorotalia tumida and G. menardii, and sporadic G. margaritae margaritae were observed in Sample 9-2, 23-25 cm. The sediments cannot be older than the Globorotalia margaritae margaritae Zone (a transition from the upper Miocene to the Pliocene); they may well include the lowermost part of the Globorotalia margaritae evoluta Zone (Pliocene). Near absence of Globorotalia margaritae s.l. prevents a precise zonal determination. Interval: from Sample 9-6, $128-130 \mathrm{~cm}$ to Sample 8-5, 17-19 cm. 


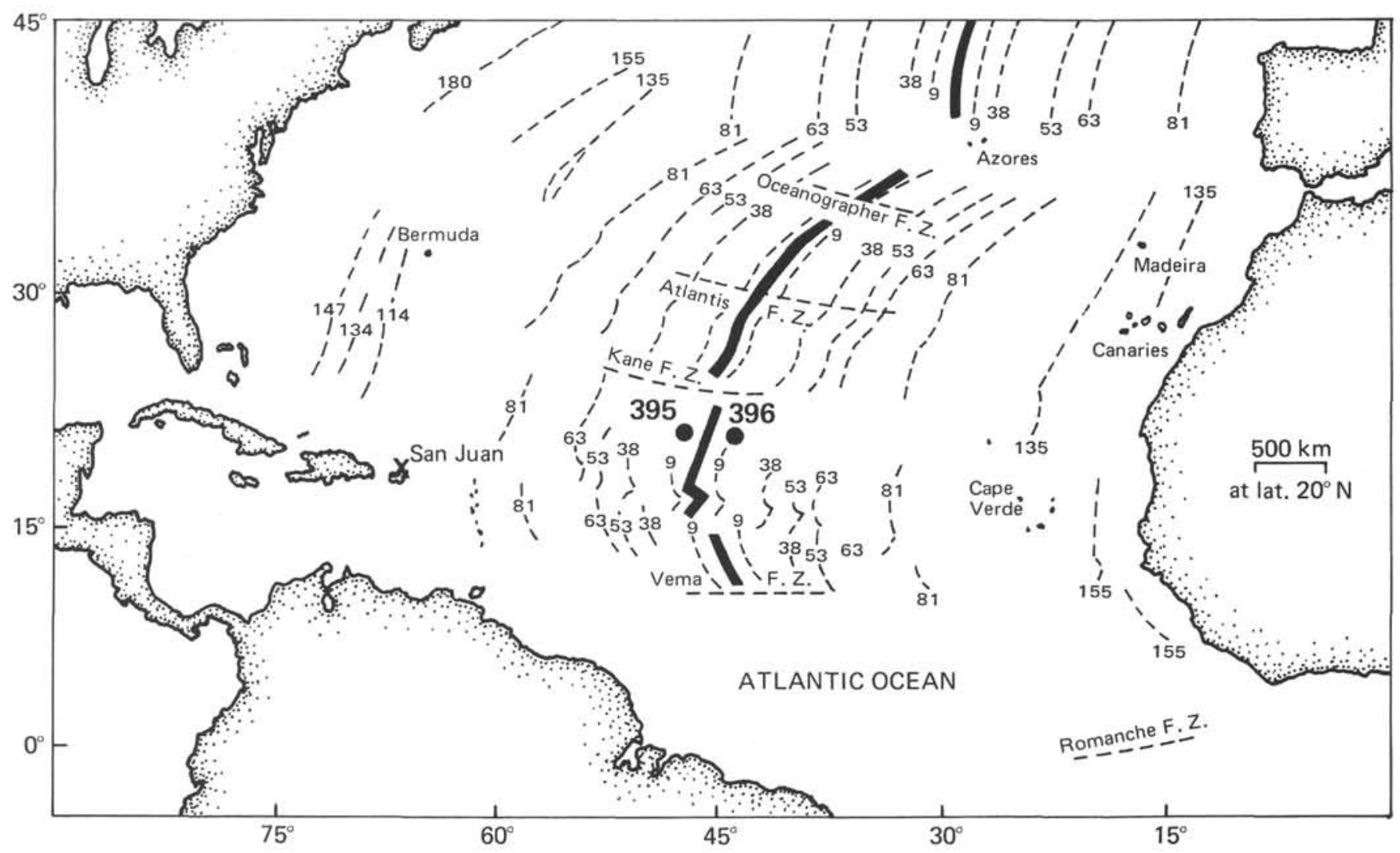

Figure 1. Location of Sites 395 and 396. Dashed lines give inferred basement ages in millions of years.

Three zones are clearly singled out in the Pliocene:

2) A foraminiferal assemblage of the Globorotalia margaritae evoluta Zone consists of Sphaeroidinella dehiscens, Sphaeroidinellopsis subdehiscens, S. seminulina, Globorotalia crassaformis, G. multicamerata, G. pseudomiocenica, G. pertenius, Globigerinoides obliquus extremus, G. ruber, G. sacculifer, G. trilobus, G. conglobatus, Orbulina universa, Globoquadrina altispira, and Globigerina nepenthes; the index species is represented by infrequent specimens. Typical specimens of Sphaeroidinella dehiscens occur in Sample 8-1, 127-129 cm; primitive forms of this species were found farther down the section. Interval: from Sample 8-3, $74-76 \mathrm{~cm}$ to Sample 6-2, 68-70 cm.

3) The Globorotalia miocenica Zone is characterized by wide distribution of the index species and $G$. exilis, G. pertenuis, G. pseudomiocenica, G. crassaformis crassaformis, and $G$. crassaformis ronda. The following species persist from the underlying deposits: Sphaeroidinella dehiscens, Orbulina universa, Globigerinoides conglobatus, G. ruber, G. sacculifer, G. trilobus; sporadic are Globoquadrina altispira, Globigerinoides pyramidalis, Globorotalia hirsuta, and G. dutertrei. Infrequent primitive Globorotalia tosaensis were recognized in the top of the zone. Interval: from Sample 5-5, 80$82 \mathrm{~cm}$ to Sample $4-4,21-23 \mathrm{~cm}$.

4) The Globorotalia tosaensis Zone, the assemblage of planktonic foraminifers that includes the index species and Globorotalia tumida, G. crassaformis (varieties crassaformis, viola, ronda, oceanica), G. hirsuta, Sphae- roidinella dehiscens, Orbulina universa, Globigerinoides conglobatus, G. ruber, G. sacculifer, and G. trilobus, associated with rarer Candeina nitida, Pulleniatina obliquiloculata, Globigerinella siphonifera, Globigerinita uvula, Globigerina quadrilatera. In the lower part of the zone, rare specimens of Globorotalia pseudomiocenica occur. Distribution of the zonal species in sediments is irregular. Globorotalia tosaensis is common in the foraminiferal assemblage of Samples 4-1, 10-12 cm and 3-4, 99-101 cm; in Samples 3-2, 75-77 cm, 3-1, $115-117 \mathrm{~cm}$, and $2-6,73-75 \mathrm{~cm}$, this species is very rare. Interval: from Sample 4-1, 10-12 cm to Sample 2-6, 73-75 cm.

Quaternary deposits conformably overlie the Pliocene. They contain abundant and diverse planktonic foraminifers: Globorotalia truncatulinoides, G. tumida, G. menardii, G. cultrata, G. dutertrei, G. crassaformis (varieties crassaformis, ronda, oceanica), G. hirsuta, Globigerinoides ruber (white), G. conglobatus, G. sacculifer, G. trilobus, Sphaeroidinella dehiscens, Candeina nitida, Pulleniatina obliquiloculata, Globigerinella siphonifera, Orbulina universa, Globigerina rubescens (white), G. bulloides, G. quinqueloba, G. quadrilatera, Globigerinita uvula.

Three subzones can be singled out within the zone concerned:

5) The Globorotalia crassaformis viola Subzone, in which the given subspecies and Globorotalia tosaensis still occur in association with $G$. truncatulinoides. The first two forms disappear in the top of the subzone. In- 
terval: from Sample 2-5, 139-141 cm to Sample 2-3, $112-114 \mathrm{~cm}$.

6) The Globorotalia crassaformis hessi Subzone, within deposits of which rare specimens of the given subsepcies were found associated with $G$. truncatulinoides, but without $G$. tosaensis and $G$. crassaformis viola. This subzone is established tentatively, because the sediments contain a sorted and redeposited fauna. Interval: from Sample 2-2, 69-71 cm up to Sample 2-1, $74-76 \mathrm{~cm}$.

7) The Globigerina calida calida Subzone, including rare specimens of $G$. aff. calida calida, Globorotalia tumida flexuosa, and more common pink Globigerina rubescens and Globigerinoides ruber. Interval: from Sample $1-5,82-84 \mathrm{~cm}$ to Sample 1-3, 142-144 cm.

Thus, Hole 395 penetrated a whole succession of Pliocene and Quaternary sediments. I did not study the uppermost Sections 1 and 2 of Core 1 . They probably correspond to the uppermost subzone of the Pleistocene (Globigerina bermudezi) and to the Holocene (the Globorotalia fimbriata Subzone)-or non-consolidated sediments of this age were shaken down the side when the drillpipe column contacted the sediment surface.

\section{Site 396}

Cenozoic sediments are in a normal contact with basalts of the oceanic basement, and can be subdivided into two lithologic units. The lower of them, 8 meters thick, consists of yellow and brown calcareous clays with interbeds of clayey nannofossil oozes. The upper unit ( $117 \mathrm{~m}$ thick) is composed of monotonous pale yellow and pale brown nannofossil oozes with subordinate interbeds of nannofossil-foraminifer oozes and foraminifer sands.

Eight stratigraphic subdivisions may be singled out (from the bottom up) by means of planktonic foraminifers:

1) Directly above the basalts there occur sediments of the Globorotalia fohsi fohsi Zone (middle Miocene), with the index species and $G$. peripheroacuta, G. peripheroronda, G. siakensis, G. obesa, G. scitula, Sphaeroidinellopsis seminulina, Orbulina suturalis, Globoquadrina altispira, G. dehiscens, G. langhiana, Globigerinoides trilobus, G. subquadratus, Globigerina bollii, and G. druryi. Thickness of middle Miocene sediments is not over 4 to 4.5 meters. Interval: from Sample 14-5, $144-146 \mathrm{~cm}$ to Sample 14-3, $99-101 \mathrm{~cm}$.

2) The upper part of brown calcareous clays is characterized by an impoverished and scarce microfauna: Globigerinoides conglobatus, G. ruber, G. obliquus obliquus, G. obliquus extremus, G. sacculifer, Globigerina nepenthes, Globoquadrina dehiscens, G. altispira, Sphaeroidinellopsis seminulina, S. subdehiscens, $S$. sphaeroides, Globorotalia menardii, G. dutertrei, G. aff. merotumida, $G$. aff. plesiotumida. Benthic foraminifers are frequent (Planulina, Eponides, Gyroidina, Cibicides, Cassidulina, Pullenia, Nonionella). These sediments can be no older than the Globorotalia margaritae margaritae Zone (transitional layers from Miocene to Pliocene), and no younger than the Globorotalia margaritae evoluta Zone (lower part of the Pliocene).
Interval: from Sample 14-2, 90-92 cm to Sample 13-6, $146-148 \mathrm{~cm}$.

Thus, a well-defined stratigraphic hiatus is responsbile for the absence of sediments of the upper middle Miocene and practically the entire upper Miocene. Higher up, the sequence of Pliocene and Quaternary sediments is continuous, and the following zones are distinguished in it: Globorotalia margaritae evoluta, $G$. miocenica, G. tosaensis (Pliocene) and G. truncatulinoides (Quaternary).

3) The planktonic foraminiferal assemblage of the Globorotalia margaritae evoluta Zone includes the index species and Globorotalia crassaformis (varieties crassaformis, ronda), G. tumida, G. menardii, G. hirsuta, G. dutertrei, G. margaritae margaritae, G. pseudomiocenica, Orbulina universa, Sphaeroidinella dehiscens, Sphaeroidinellopsis subdehiscens, S. seminulina, S. sphaeroides, Globoquadrina altispira, G. dehiscens, Globigerinoides conglobatus, G. ruber, G. sacculifer, G. trilobus, G. obliquus obliquus, G. obliquus extremus, and Globigerina nepenthes. Interval: from Sample 13-5, $109-111 \mathrm{~cm}$ to Sample 11-6, $89-91 \mathrm{~cm}$.

4) The Globorotalia miocenica Zone includes the index-species and G. pertenuis, G. multicamerata, G. exilis, G. crassaformis (varieties crassaformis, ronda, oceanica), G. pseudomiocenica, G. dutertrei, G. hirsuta, Orbulina universa, Sphaeroidinella dehiscens, Globigerinoides ruber, G. conglobatus, G. sacculifer, G. trilobus, and Candeina nitida. In the top of the zone rare specimens of Globorotalia crassaformis viola occur. Interval: from Sample 11-4, 134-136 cm to Sample 8-2, 73-75 $\mathrm{cm}$.

5) The Globorotalia tosaensis Zone is characterized by the index species and Globorotalia crassaformis (varieties crassaformis, viola, ronda, oceanica), G. hirsuta, G. dutertrei, G. menardii, Orbulina universa, Sphaeroidinella dehiscens, Globigerinella siphonifera, Candeina nitida, Pulleniatina obliquiloculata, Globigerinita uvula, Globigerinoides conglobatus, G. ruber, G. sacculifer, G. trilobus, and Globigerina spp. Interval: from Sample $7-6,74-76 \mathrm{~cm}$ to Sample 5-3, $125-127 \mathrm{~cm}$.

The change of planktonic foraminifers at the Pliocene/Quaternary boundary testifies to the absence of a stratigraphic gap: upper Pliocene sediments (Globorotalia tosaensis Zone) are replaced by lower Quaternary nannofossil oozes (Globorotalia crassaformis viola Subzone). Nevertheless, it is impossible to determine the exact position of the boundary: in Sample 5-1, 116$118 \mathrm{~cm}$, there are only minute, well-sorted tests of Globigerina, Globigerinita, and Globigerinoides; recovery in Core 4 was nil.

In the Globorotalia truncatulinoides Zone (Quaternary), a rich association of planktonic foraminifers is developed: Globorotalia truncatulinoides, G. crassaformis s.l., G. tumida, G. menardii, G. hirsuta, G. dutertrei, G. cultrata, Sphaeroidinella dehiscens, Candeina nitida, Orbulina universa, Pulleniatina obliquiloculata, Globigerinoides sacculifer, G. ruber (white), G. trilobus, G. conglobatus, Globigerinita uvula, Globorotaloides variabilis, Globigerinella siphonifera, Globigerina rubescens (white), G. calida praecalida, G. bulloides. Glo- 
borotalia inflata occurs sporadically. Three subzones can be singled out within the zone concerned, as follows:

6) The Globorotalia crassaformis viola Subzone, where this subspecies and Globorotalia tosaensis occur together with $G$. truncatulinoides. Interval: from Sample $3-3,86-88 \mathrm{~cm}$ to Sample $2-5,139-141 \mathrm{~cm}$.

7) The Globorotalia crassaformis hessi Subzone, identified by distribution of the given subspecies. In the basal layers of the subzone, sporadic G. crassaformis viola were recovered, and somewhat higher up, extremely rare specimens of $G$. tosaensis. One cannot exclude, however, the possibility of their redeposition from underlying deposits. Interval: from Sample 2-4, $83-85 \mathrm{~cm}$ to Sample 1-2, 121-123 cm.

8) The Globigerina calida calida Subzone, where rare specimens of $G$. aff. calida calida occur together with common Globorotalia tumida flexuosa and pink Globigerinoides ruber and Globigerina rubescens. Interval: Sample 1-1, 139-141 cm.

Uppermost Pleistocene sediments (Globigerina bermudezi Subzone) and those of the Holocene (Globorotalia fimbriata Subzone) were not recovered, probably because of their negligible thickness and non-consolidated character.

\section{MAIN FEATURES OF PLANKTONIC FORAMINIFER ASSEMBLAGES AND ZONAL STRATIGRAPHY OF THE NEOGENE AND QUATERNARY}

Rich assemblages of Neogene and Quaternary planktonic foraminifers in the region of Sites 395 and 396 are of a well-defined tropical and subtropical character. They include species of Globorotalia, Orbulina, Candeina, Pulleniatina, Sphaeroidinella. Sphaeroidinellopsis, Globigerinoides, and Globigerina that were, in general, common to the tropical and subtropical belt of the world ocean in Neogene and Pleistocene time. As to their quantities, species of Globigerina are less abundant than those of Globigerinoides and Globorotalia. The index species of the moderate belt (Globorotalia inflata, Globigerina bulloides) are rare.

In this connection, the same zonal scale as in other regions of the tropical and subtropical belt is used for the stratigraphic subdivision of Neogene and Quaternary sediments. The Globorotalia fohsi fohsi Zone (Site
396) was identified in the Neogene. In the Pliocene and Quaternary of Sites 395 and 396, the same succession of zones and subzones has been identified: Globorotalia margaritae evoluta, Globorotalia miocenica, Globorotalia tosaensis, Globorotalia truncatulinoides (with the Globorotalia crassaformis viola, Globorotalia crassaformis hessi, and Globigerina calida calida subzones).

It should be emphasized that the same subzones can be identified in Quaternary sediments as in the Caribbean basin (Leg 15), near the western coast of Africa (Leg 41), and in the Tymor trough of the Indian Ocean (Leg 27). The presence of Globorotalia tosaensis in the upper Pliocene enables us to trace the line G. tosaensis-G. truncatulinoides, and to establish the boundary of Pliocene and Quaternary sediments.

In Pliocene-Quaternary sediments of Sites 395 and 396 , one can observe redeposited planktonic foraminifers, perfect sorting of tests by size, and accumulation of minute juvenile specimens of foraminifers. Similar mixed assemblages were recognized in the following samples:

395-2-1, 74-76 cm,
$2-2,69-71 \mathrm{~cm}$,
$2-6,73-75 \mathrm{~cm}$,
$3-4,99-101 \mathrm{~cm}$,
$3-6,90-92 \mathrm{~cm}$,
$4-4,115-117 \mathrm{~cm}$,
$5-3,67-69 \mathrm{~cm}$,
$6-2,68-70 \mathrm{~cm}$,
$9-4,50-52 \mathrm{~cm}$,
$396-3-1,87-89 \mathrm{~cm}$,
$3-3,86-88 \mathrm{~cm}$,
$5-1,116-118 \mathrm{~cm}$,

5-3, $125-127 \mathrm{~cm}$, $5-5,74-76 \mathrm{~cm}$, 6-2, $82-84 \mathrm{~cm}$, 6-4, $105-107 \mathrm{~cm}$, 6-6, $86-88 \mathrm{~cm}$, 7-2, $96-99 \mathrm{~cm}$, 9-2, 8-10 cm, 9-4, 64-66 cm, 10-3, 120-122 cm, $10-5,108-110 \mathrm{~cm}$, $13-3,66-68 \mathrm{~cm}$.

The occurrence of such heterogeneous and sorted planktonic foraminifer assemblages results from the influence of bottom turbidity currents along the slopes of the ridges (sedimentary ponds of Sites 395 and 396 are arranged at the base of high underwater ridges). Along with these assemblages, normal (natural) assemblages of foraminifers are frequently present. Hence, the influence of turbidity currents was not constant in time. The wide distribution of heterogeneous assemblages of planktonic foraminifers is certain to affect the exactness of drawing the stratigraphic boundaries. 